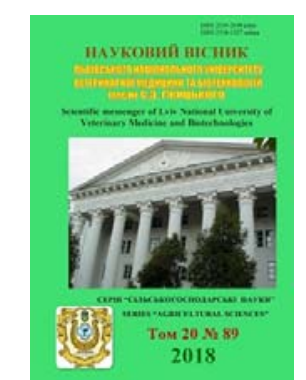
ветеринарної медицини та біотехнологій імені С.3. Гжицького

\author{
Scientific Messenger of Lviv National University \\ of Veterinary Medicine and Biotechnologies
}

UDC 633.2: 631.81

\title{
The influence of single-species crops and their grass mixes on the grass species composition
}

\author{
L.K. Savchuk, I.V. Vyhovsky \\ Rivne State Humanitarian University, Rivne, Ukraine
}

Article info

Received 27.08.2018 Received in revised form 24.09 .2018 Accepted 25.09.2018

Rivne State Humanitarian University, Stepan Bandera Str. 12, Rivne, 33028,Ukraine. Tel.: +38-067-907-21-48 E-mail: lubasav4uk@gmail.com, vugovsky@ukr.net
Savchuk, L.K., \& Vyhovsky, I.V. (2018). The influence of single-species crops and their grass mixes on the grass species composition. Scientific Messenger of Lviv National University of Veterinary Medicine and Biotechnologies, 20(89), 3-7. doi: 10.32718/nvlvet8901

When creating artificial phytocoenoses, the main task is to create optimal conditions for growth and development, in accordance with the needs of each type of cultivated plants, which would ensure the highest productivity of the group during the entire period of use of herbs and the production of high quality and cheap feed for public livestock breeding. In order to successfully solve the problem of regulating the composition of agrophytocenoses in scientific and practical buckling, it is important to know how the relations between plants in the process of their joint growth and development occurs, which changes take place in the botanical composition not only in species groups, but also in single-species crops of grasses on the eroded slope of steepness 6-7 $7^{\circ}$ on the basis of Rivne Institute of Agro-Industrial Production of the National Academy of Agricultural Sciences of Ukraine. The results of research showed that it is economically expedient to grow grass-legume grass mixtures with a longer period of productive longevity using the low nitrogen fertilizer rates, which contributes to the formation of phytocenosis, in which valuable species of cereal and perennial bean grasses (beetroot grass and alfalfa sowing). The positive effect on the species composition of the grass was slight mowing in the phase of tubing. The results of the research showed that for the production of grass-legume grass, the hay-grass-free use should be sown with grass mixtures, the following herbs were added to the composition: alfalfa sowed (4.4 million pounds per hectare) + long beetroot horned (4.4 million pounds per hectare) + bromus inermis (3.4 million pounds per hectare) + lolium perenne (3.4 million pounds per hectare) of conditioned seeds that affect the species composition of the grass during the growing season. On the basis of the conducted researches it was established that the analysis of the species composition of the herb shows that the quantitative correlation of the species varied over the years, mainly from the biological characteristics of herbs that were part of the grass mixture. The percentage of sown species of grasses has grown with the age of grass. The results of researches, which showed that in four component grass mixtures, in the fertilization of grass with complete mineral fertilizers in the norm $N_{60} P_{60} K_{90}$, dominant legume perennial grasses - beetroot horn $(25.0 \%)$, alfalfa seed $(30.9 \%)$, and cereals stokolos seamless (21.7\%) and Lolium multiflorum (13.0\%). In a small number, during the years of research, self-seedling appeared timothy bean (2.0\%), non-infected cereals $(4.0 \%)$ and herbs $-3.4 \%$. During the years of research on varieties, which were planted with alfalfa seed and beetroot, bean herbs predominated. The percentage of hare cattle was $88.5 \%$, alfalfa seeded $91.4 \%$.

Key words: hayfields, eroded slopes, meadow grass, fertilization, species composition of grass.

\section{Вплив одновидових посівів та їх травосумішок на видовий склад травостою}

\author{
Л.К. Савчук, І.В. Виговський
}

Рівненський державний гуманітарний університет, м. Рівне, Украӥна

При створенні штучних фітоценозів основним завданням є формування оптимальних умов росту і розвитку, відповідно до потреб кожного виду культурних рослин, які б забезпечили найвищу продуктивність угруповання протягом усього періоду користування травостоєм та виробництва високоякісних і дешевих кормів для громадського тваринництва. Для успішного вирішення проблеми регулювання складу агрофітоценозів у науковому та практичному луківництві важливо знати, як саме складаються взаємовідносини рослин у процесі їх сумісного росту та розвитку, які зміни відбуваються в ботанічному складі не тільки в різно- 
видових угрупованнях, а й в одновидових посівах трав на еродованому схилі крутизною 6-7 на базі Рівненського інституту агропромислового виробництва НААН України. Подано результати досліджень, які засвідчили, щзо економічно дочільніше на схилових землях вирощувати злаково-бобові травосумішки з довшим періодом продуктивного довголіття, використовуючи при иьому невисокі норми азотних добрив, щзо сприяє утворенню фітоценозу, в якому переважають цінні види злакових та багаторічні бобові трави (лядвенеиь рогатий та лючерна посівна). Позитивний вплив на видовий склад травостою мало скошування у фазі трубкування. Наведені результати досліджень показали, щчо для створення злаково-бобового травостою сінокісного використання безпокривним способом потрібно висівати травосумішку, в склад якої введено такі трави: люцерна посівна (4,4) + лядвенець рогатий $(4,4)+$ стоколос безостий $(3,4)+$ пажитниця багатоукісна $(3,4)$ млн. шт./га кг/га кондиційного насіння, які впливають на видовий склад травостою протягом вегетаційного періоду. На основі проведених досліджень встановлено, щзо аналіз видового складу травостою свідчить, щзо кількісне співвідношення видів змінювалося за роками, в основному від біологічних особливостей трав, цчо входили до травосумішки. Відсоток сіяних видів трав підвищився з віком травостою. Подано результати досліджень, які засвідчили, щу у чотири компонентних травосумішках, при удобренні травостою повним мінеральним удобренням в нормі $N_{60} P_{60} K_{90}$ домінували в основному бобові багаторічні трави - лядвенець рогатий (25,0\%), люиерна посівна (30,9\%), а із злакових - стоколос безостий $(21,7 \%)$ та пажитниця багатоукісна $(13,0 \%)$. У незначній кількості за роки досліджень самосівом появились тимофївка лучна (2,0\%), несіяні злаки (4,0\%) та різнотрав'я - 3,4\%. За роки дослідження на варіантах, де було висіяно люиерну посівну $і$ лядвенець рогатий, переважали бобові трави. Відсоток лядвенцю рогатого становив - 88,5\%, лючерни посівної-91,4\%.

Ключові слова: сінокоси, еродовані схили, лучні трави, удобрення, видовий склад травостою.

\section{Вступ}

Виробництво високоякісних і дешевих кормів для громадського тваринництва було, є і залишається надзвичайно актуальною проблемою. Особливо важливе це питання, коли йдеться про використання еродованих силових земель, виведених із обробітку в умовах Лісостепу західного. Економічно доцільніше на еродованих схилових землях вирощувати злаковобобові травосумішки 3 довшим періодом продуктивного довголіття, використовуючи при цьому невисокі норми мінеральних добрив (Vyhovsky, 2018). У Рівненській області під постійне залуження передбачено вивести низькопродуктивні еродовані схилові землі. Сіяні травостої через недостатнє удобрення і перенавантаження поголів'ям ВРX дуже скоро деградуються. Висіяні види і навіть сорти районованих трав на таких травостоях або не досягають запланованої продуктивності, або передчасно випадають, і їхній біологічний потенціал вегетативного самовідновлення не використовується. Застосування моніторингу стану ботанічного i видового складу травостою, стану грунтів дозволить своєчасно вжити заходи до підвищення продуктивності, якості корму. Тому виникла потреба використання нових видів багаторічних бобових трав, зокрема такого невибагливого і довговічного виду, як лядвенець рогатий (Lotus corniculatus L.). Багаторічна бобова рослина, яка має добре розвинену кореневу систему. Після випасання i скошування швидко відростає і довго тримається в травостої. Тварини охоче поїдають його. За сприятливих умов лядвенець рогатий дає три укоси. Використання цього виду багаторічних бобових трав вимагає розробки елементів технології вирощування злаково-бобових травосумішок на його основі (Mashchak, 2005).

Поліпшених лучних угідь дозволить визначити темпи розвитку даних агроекосистем, вивчити фіторізноманіття, а всебічний аналіз видового складу травостою дасть змогу встановити роль сіяних трав в агроценозі, причини їхнього випадання із загального складу і появи інших несіяних видів.
Рослини, тварини, мікрофлора, грунт - це складні цілісні системи, в яких всі складові тісно пов'язані між собою процесами обміну речовин на сіяних та природних луках (Pukalo and Vyhovskii, 2015). Але їх рослинні компоненти не завжди відповідають екологічним умов місцезнаходження, в результаті чого вони сильно змінюються, особливо на початкових стадіях розвитку. Тому потрібен час, щоб травостій, грунт і мікрофлора досягли рівноваги, яка характерна для природних лук (Buhryn et al., 2000).

Найефективнішими в кормовиробництві $\epsilon$ низькозатратні системи, які передбачають використання довготривалих лучних травостоїв, зокрема на схилових землях, i мають високий біологічний потенціал (Abramovych, 2004).

\section{Матеріал і методи досліджень}

Експериментальні дослідження проводили на темно-сірих опідзолених легкосуглинкових, середньозмитих, виведених під залуження грунтах дослідних ділянок Рівненського інституту агропромислового виробництва НААН України на схилах південнозахідної експозиції крутизною 6-7․ Для створення травостою сінокісного використання безпокривним способом висівали такі сорти трав: люцерна посівна сорт Ярославна; лядвенець рогатий сорт Аякс; пажитниця багатоукісна сорт Київський; тимофіївка лучна сорт Підгірянка; стоколос безостий сорт Марс. Для визначення видового складу, відбирались проби зеленої маси $з$ чотирьох площинок по 0,25 м² 3 поділом на ботаніко-господарські групи: злаки, бобові, різнотрав'я (Babych, 1994).

Всі варіанти досліду зі злаково-бобовим травосто$\epsilon \mathrm{y}$ уобрювали мінеральними добривами в дозі $\mathrm{N}_{60} \mathrm{P}_{60} \mathrm{~K}_{90}$, а бобові трави - в дозі $\mathrm{P}_{60} \mathrm{~K}_{90}$. Азотні добрива вносили в дозі $\mathrm{N}_{30}$ весною і після другого укосу. Фосфорні та калійні - навесні. Погодні умови в роки проведення досліджень були сприятливими для вирощування багаторічних трав, хоча в літні періоди спостерігали недостатню кількість опадів. 
Таблиця 1

Схема досліду

\begin{tabular}{|c|c|}
\hline Варіанти & Травосумішка \\
\hline 1 & Люцерна посівна - 11 млн шт./га \\
\hline 2 & Лядвенець рогатий - 11 млн шт./га \\
\hline 3 & Люцерна посівна (7,4 млн шт./га) + лядвенець рогатий (7,3 млн шт./га) \\
\hline 4 & $\begin{array}{l}\text { Люцерна посівна (4,4 млн шт./га) + лядвенець рогатий }(4,4 \text { млн шт./га) + пажитниця багатоукісна } \\
\text { (6,8 млн шт./га) }\end{array}$ \\
\hline 5 & $\begin{array}{l}\text { Люцерна посівна (4,4 млн шт./га) + лядвенець рогатий (4,4 млн шт./га) + тимофіївка лучна } \\
\text { (6,8 млн шт./га) }\end{array}$ \\
\hline 6 & $\begin{array}{l}\text { Люцерна посівна (4,4 млн шт./га) + лядвенець рогатий }(4,4 \text { млн шт./га) + стоколос безостий } \\
(3,4 \text { млн шт./га) + тимофіївка лучна (3,4 млн шт./га) }\end{array}$ \\
\hline 7 & $\begin{array}{l}\text { Люцерна посівна }(4,4 \text { млн шт./га) + лядвенець рогатий }(4,4 \text { млн шт./га) + стоколос безостий } \\
(3,4 \text { млн шт./га)+пажитниця багатоукісна(3,4 млн шт./га) }\end{array}$ \\
\hline
\end{tabular}

\section{Результати та їх обговорення}

Одними із можливих методів зниження затрат при створенні сіножатей на схилових землях і виробництві 3 них кормів, як свідчать раніше проведені дослідження, можна досягти шляхом підбору одновидових посівів та їх травосумішок адаптованих до місцевих умов кормових культур (Bohovin et al., 2005).

При сівбі в одному масиві злаково-бобових травосумішок, компонентами яких були види трав різних строків дозрівання, в середньому за вегетаційний період використання найвищу урожайність на силових землях забезпечила травосумішка, яка складалась 3 люцерни посівної, лядвенцю рогатого, стоколосу безостого, пажитниці багатоукісної. Сінокісне використання даної травосумішки при мінеральному удобренні в нормі $\mathrm{N}_{60} \mathrm{P}_{60} \mathrm{~K}_{90}$ забезпечує продуктивність сухої маси 6,9 ц/га або 5,09 т/га кормових одиниць (Lavres et al., 2004; Mashchak et al., 2010).

Створюючи штучні ценози сінокісного використання, для поступової заміни однорічних трав більш довговічними, слід включати до їх складу тимофіївку лучну та стоколос безостий як утворювачів основи стабільного угруповання. Враховуючи нетривале продуктивне довголіття пажитниці багатоукісної, травосумішки з включенням даного виду придатні тільки для короткотермінового використання.

Таким чином, багаторічні трави, маючи різний генетичний та фітоценотичний потенціал, перебуваючи в однакових екологічних умовах, беруть різну участь у формуванні травостою залежно від складу травосумішки.

Вміст у травостої висіяних культур одновидових посівів бобових багаторічних трав за роки користування травостоєм був досить високим і складав 8991\% в першому укосі та 93-96\% - третьому. Така ж сама закономірність стабільної участі в рослинному угрупованні цих компонентів спостерігається і у складній злаково-бобовій травосумішці, де досить стійким домінантом виступала люцерна посівна. Дольова частка люцерни посівної і лядвенцю рогатого в злаково-бобовому травостої, до якого входили злакові багаторічні трави, на третій рік життя зменшилась. Крім цього тривалість життя бобових видів багаторічних трав у злаково-бобовому травостої значно менша порівняно з їхньою тривалістю життя в одновидових посівах.

Аналіз видового складу травостою показав, що кількісне співвідношення видів змінювалося за роками, в основному від біологічних особливостей видів, що входили до травосумішки (табл. 2).

\section{Таблиця 2}

Видовий склад травостою залежно від одновидових посівів та їхніх травосумішок

\begin{tabular}{|c|c|c|c|c|c|c|c|}
\hline \multirow[b]{2}{*}{ Схема досліду } & \multicolumn{3}{|c|}{ Злаки } & \multirow{2}{*}{$\begin{array}{l}\text { Несіяні } \\
\text { злаки }\end{array}$} & \multicolumn{2}{|c|}{ Бобові } & \multirow{2}{*}{$\begin{array}{l}\text { Різнот- } \\
\text { рав'я }\end{array}$} \\
\hline & $\begin{array}{c}\text { пажитниця } \\
\text { багатоукісна } \\
\end{array}$ & $\begin{array}{l}\text { тимофіївка } \\
\text { лучна }\end{array}$ & $\begin{array}{l}\text { стоколос } \\
\text { безостий }\end{array}$ & & $\begin{array}{c}\text { люцерна } \\
\text { посівна }\end{array}$ & $\begin{array}{l}\text { лядвенець } \\
\text { рогатий }\end{array}$ & \\
\hline Люцерна посівна & - & - & - & 5,47 & 91,4 & - & 3,13 \\
\hline Лядвенець рогатий & - & - & - & 7,0 & - & 88,5 & 4,5 \\
\hline Люцерна посівна + лядвенець рогатий & - & - & - & 6,7 & 48,5 & 39,7 & 5,1 \\
\hline $\begin{array}{l}\text { Люцерна посівна + лядвенець рогатий + } \\
\text { пажитниця багатоукісна }\end{array}$ & 35,0 & 1,0 & 1,35 & 4,55 & 21,1 & 30,95 & 6,05 \\
\hline $\begin{array}{l}\text { Люцерна посівна + лядвенець рогатий }+ \\
\text { тимофіївка лучна }\end{array}$ & 0,9 & 33,1 & 2,3 & 3,8 & 27,2 & 23,0 & 9,70 \\
\hline $\begin{array}{l}\text { Люцерна посівна }+ \text { лядвенець рогатий }+ \\
\text { стоколос безостий + тимофіївка лучна }\end{array}$ & 1,9 & 13,0 & 18,2 & 4,1 & 33,1 & 20,6 & 9,10 \\
\hline $\begin{array}{l}\text { Люцерна посівна }+ \text { лядвенець рогатий }+ \\
\text { стоколос безостий }+ \text { пажитниця } \\
\text { багатоукісна }\end{array}$ & 13,0 & 2,0 & 21,7 & 4,0 & 30,9 & 25,0 & 3,40 \\
\hline
\end{tabular}


Як видно із результатів наших досліджень, частка висіяних культур була досить високою і змінювалась за роками користування травостоєм залежно від виду трав та складу травосумішки. Різнотрав'я, хоч i з'являлося протягом розвитку агроценозу, але воно було пригнічене сіяними травами і на урожай мало впливало, особливо на третьому році життя травостою (Vyhovsky, 2014; Vyhovsky, 2017).

Найбільш раннє відростання після весняного відновлення вегетації спостерігалось на злаково-бобовій травосумішці, що складається із люцерни посівної, лядвенцю рогатого, стоколосу безостого та пажитниці багатоукісної, а з бобових у люцерни посівної. За рахунок поєднання різностиглих травостоїв у кожному укосі на 5-7 днів є можливість продовжити оптимальний строк сінозбирання і цим самим створити сприятливі умови для більш раціонального використання трудових ресурсів та технічних засобів, заготовляти високоякісні корми навіть за несприятливої погоди, без втрат якості корму.

На варіантах, де було висіяно люцерну посівну i лядвенець рогатий, переважали бобові трави та самовисівом з'явились злакові трави, яких було відмічено 5,47-7,04\%, частково різнотрав'я, яке складало 3,13$5,1 \%$. Зі злакових трав переважав пирій повзучий, а із різнотрав'я - ромашка біла, деревій та кульбаба.

У середньому за роки досліджень в травостої злаково-бобової травосумішки домінантом виступала та злакова трава, яку висівали разом із бобовими травами.

На варіанті, де було висіяно травосумішку, яка складалась 3 люцерни посівної, лядвенцю рогатого i тимофіївки лучної найбільша частка припадала на тимофіївку лучну і складала 33,1\%, дещо менше на люцерну посівну - 27,2\% та лядвенець рогатий 23,0\%. У незначній кількості, за роки досліджень, самосівом появились пажитниця багатоукісна (0,9\%), стоколос безостий (2,3\%) і несіяні злаки $(3,8 \%)$ та різнотрав'я - 9,7\%

У чотири компонентних травосумішках, до складу яких було введено наступні трави: люцерна посівна $(4,4)+$ лядвенець рогатий $(4,4)+$ стоколос безостий $(3,4)+$ пажитниця багатоукісна $(3,4)$ млн шт./га, при удобренні травостою повним мінеральним удобренням в нормі $\mathrm{N}_{60} \mathrm{P}_{60} \mathrm{~K}_{90}$, за час проведення досліджень домінували в основному бобові багаторічні трави лядвенець рогатий $(25,0 \%)$, люцерна посівна $(30,9 \%)$, а зі злакових - стоколос безостий $(21,7 \%)$, пажитниця багатоукісна (13,0\%). У незначній кількості самосівом появились тимофіївка лучна $(2,0 \%)$, несіяні злаки $(4,0 \%)$ та різнотрав'я $-3,4 \%$.

Серед бобових трав найбільшу частку у травостої займали люцерна посівна та лядвенець рогатий, які є конкурентостійкими у лучних ценозах навіть за сприятливих умов розвитку природних і сіяних популяцій злаків та різнотрав'я.

Частка різнотрав'я на всіх варіантах досліду складала 3,13-9,7\%. Найбільший відсоток різнотрав'я був на варіанті, де висівали люцерну посівну, лядвенець рогатий, тимофіївку лучну і складався 3 ромашки білої, кульбаби звичайної та деревію звичайного. В незначній кількості зустрічався осот прибережний.

\section{Висновки}

Проведеними нами дослідженнями встановлено, що видовий склад злаково-бобової травосумішки сінокісного використання для постійного залуження змінювався за роками під впливом мінеральних добрив.

Багаторічні трави, маючи різний генетичний та фітоценотичний потенціал, перебуваючи в однакових екологічних умовах, беруть різну участь у формуванні травостою залежно від складу травосумішки.

Аналіз видового складу травостою показав, що на варіантах зі злаково-бобовим травостоєм в агроценозі серед злакових трав переважав стоколос безостий $(21,7 \%)$ та пажитниця багатоукісна $(13,0 \%)$, а із бобових - люцерна посівна $(30,9 \%)$ та лядвенець рогатий $(25,0 \%)$.

За роки дослідження на варіантах, де було висіяно люцерну посівну і лядвенець рогатий, переважали бобові трави. Дольова участь лядвенцю рогатого становила $-88,5 \%$, люцерни посівної - 91,4\%.

Найвищий відсоток лядвенцю рогатого (30,95\%) відмічено на варіанті з люцерною посівної, лядвенцем рогатим та пажитницею багатоукісною.

\section{References}

Abramovych, S.Ia. (2004). Systema vedennia silskohospodarskoho vyrobnytstva $\mathrm{v}$ hospodarstvakh Rivnenskoi oblasti. Rivnenska derzhavna s.-h. stantsiia Tsentr naukovoho zabezpechennia APV Rivnenskoi oblasti. Rivne (in Ukrainian).

Babych, A.O. (1994). Metodyka provedennia doslidiv po kormovyrobnytstvu. Vinnytsia (in Ukrainian).

Bohovin, A.V., Sliusar, I. T., \& Tsarenko, M.K. (2005). Travianysti bioheotsenozy, yikhnie polipshennia ta ratsionalne vykorystannia. K. Ahrarna nauka (in Ukrainian).

Buhryn, L.M., Mashchak, Ya.I., \& Liubchenko, L.M. (2000). Osoblyvosti formuvannia luchnykh fitotsenoziv ta vyrobnytstvo kormovoho bilka. Peredhirne ta hirske zemlerobstvo i tvarynnytstvo, 43, 9-13 (in Ukrainian).

Lavres, J., Ferragine, M.D.C., Gerdes, L., Raposo, R.W.C., da Costa, M.N.X., \& Monteiro, F.A. (2004). Yield components and morphogenesis of Aruana grass in response to nitrogen supply Componentes de produção e morfogênese do capim-Aruana em resposta ao nitrogênio. Scientia Agricola. 61(6), 632639. doi: 10.1590/S0103-90162004000600011.

Mashchak, Ya.I. (2005). Lukivnytstvo v teoriï i praktytsi. Lviv: Spolom (in Ukrainian).

Mashchak, Ya.I., Liubchenko, L.M., \& Vyhovskyi, I.V. (2010). Produktyvnist luchnykh tsenoziv na erodovanykh zemliakh na nahromadzhennia korenevoi masy zalezhno vid vydovoho skladu siianykh trav i yikh travosumishok. Peredhirne ta hirske zemlerobstvo i tvarynnytstvo, 52, 64-69 (in Ukrainian).

Pukalo, D. L., \& Vyhovskii, I. V. (2015). Economical evaluation of grass-herbage legumes depending on soil processing and grass mixtures. Scientific Messenger of LNU of Veterinary Medicine and 
Biotechnologies, 17(1), 162-166. Retrieved from https://nvlvet.com.ua/index.php/journal/article/view/4 25.

Vyhovsky, I.V. (2017). Composition of mineral elements in the yield of one-species sows of perennial grasses and their mixtures. Scientific Messenger LNUVMBT named after S.Z. Gzhytskyj, 19(74), 140-142. doi: 10.15421/nvlvet7431.

Vyhovsky, I.V. (2018). Removal of nourishing substances with meadow grass harvest. Scientific Messenger of
Lviv National University of Veterinary Medicine and Biotechnologies, 20(84), 49-53. doi: 10.15421/nvlvet8409.

Vyhovskyi, I.V. (2014). Formuvannia travostoiu zalezhno vid odnovydovykh posiviv i yikh travosumishok. Naukovyi visnyk LNUVMB im. S.Z. Gzhytskoho, 16, 3(60). 32-38. (in Ukrainian). 